Thiago Saads Carvalho(a)

Helen Moura Kehrle ${ }^{(a)}$

Fábio Correia Sampaio(b)

(a) DDSs; (b)Professor of Clinical Cariology School of Dentistry, Federal University of Paraíba.

\author{
Corresponding author: \\ Thiago Saads Carvalho \\ Av. Nego, 935, apto. 202 \\ (Ed. Camboriú), Tambaú \\ João Pessoa - PB - Brazil \\ CEP: 58039-101 \\ E-mail: thiagosaads@hotmail.com
}

Received for publication on Jan 12, 2006 Sent for alterations on Nov 24, 2006

Accepted for publication on Apr 13, 2007

\section{Prevalence and severity of dental fluorosis among students from João Pessoa, PB, Brazil}

\author{
Prevalência e severidade de fluorose dentária \\ em escolares da cidade de João Pessoa, PB, \\ Brasil
}

\begin{abstract}
The aim of this study was to determine the prevalence and severity of dental fluorosis among 12-15-year-old students from João Pessoa, PB, Brazil before starting a program of artificial fluoridation of drinking water. The use of fluoridated dentifrice was also surveyed. A sample of 1,402 students was randomly selected. However, 31 students refused to participate and 257 were not permanent residents in João Pessoa, thus leaving a final sample of 1,114 students. Clinical exams were carried out by two calibrated dentists (Kappa $=0.78)$ under natural indirect light. Upper and lower front teeth were cleaned with gauze and dried, and then examined using the TF index for fluorosis. A questionnaire on dentifrice ingestion and oral hygiene habits was applied to the students. The results revealed that fluorosis prevalence in this age group was higher than expected $(29.2 \%)$. Most fluorosis cases were TF $=1(66.8 \%)$, and the most severe cases were TF $=4$ $(2.2 \%)$. The majority of the students reported that they had been using fluoridated dentifrices since childhood; $95 \%$ of the participants preferred brands with a 1,500 ppm F concentration, and $40 \%$ remembered that they usually ingested or still ingest dentifrice during brushing. It was concluded that dental fluorosis prevalence among students in João Pessoa is higher than expected for an area with non-fluoridated water. However, although most students use fluoridated dentifrices, and almost half ingest slurry while brushing, the majority of cases had little aesthetic relevance from the professionals' point of view, thus suggesting that fluorosis is not a public health problem in the locality.
\end{abstract}

Descriptors: Dental fluorosis; Fluorides; Dentifrices.

Resumo: O objetivo deste estudo foi determinar a prevalência e severidade de fluorose dentária em escolares de 12 a 15 anos de idade de João Pessoa, PB, Brasil antes da implantação de um programa de fluoretação de águas. O uso de dentifrício fluoretado também foi investigado. De 1.402 escolares aleatoriamente selecionados, 31 recusaram-se a participar, 257 não eram residentes permanentes na cidade, resultando em uma amostra final de 1.114 escolares. Dois cirurgiões-dentistas calibrados (Kappa $=0,78)$ realizaram exames clínicos sob luz natural indireta nos dentes anteriores superiores e inferiores limpos com gaze e secos, aplicando-se o índice TF para fluorose. Um questionário sobre ingestão de dentifrício e hábitos de higiene oral foi aplicado. Os resultados demonstram uma prevalência de fluorose acima do esperado $(29,2 \%)$. A maioria dos casos foi TF $=1(66,8 \%)$, e os mais severos foram TF $=4(2,2 \%)$. A maioria dos estudantes informou que faz uso de dentifrícios desde a infância; $95 \%$ dos participantes preferiam marcas com 1.500 ppm $\mathrm{F}$ e $40 \%$ confirmaram que usualmente ingeriam ou ainda ingerem dentifrício durante a escovação. Conclui-se que a prevalência de fluorose entre estudantes de João Pessoa é acima do esperado para uma cidade sem fluoretação de águas. No entanto, apesar de a maioria dos estudantes usar dentifrícios fluoretados, e quase a metade deles ingerir dentifrício quando escova, a maioria dos casos foi de pouco comprometimento estético sob o ponto de vista dos profissionais, o que sugere que a fluorose não se constitui em um problema de saúde pública nesta localidade.

Descritores: Fluorose dentária; Fluoretos; Dentifrícios. 


\section{Introduction}

The use of fluoride in dental products, especially in dentifrices, has been considered as one of the main reasons for caries decline in several countries and industrialized areas of Brazil. 3,7,13,30

Fluoride can, however, induce toxic effects. Chronic intoxication with fluoride affects the tooth mineralization process, resulting in hypomineralized enamel which is characterized by greater porosity than that of normal enamel. This condition is called dental fluorosis. ${ }^{28}$ The severity of the fluorotic enamel depends on the dose and on the duration of fluoride exposure. ${ }^{29}$

Reports on the prevalence of dental fluorosis in Brazil show a wide variation. ${ }^{10}$ In addition to the different risk factors, it is also necessary to understand that several epidemiological indices have been used to measure fluorosis. ${ }^{23}$ So far, dental fluorosis is a public health problem in few Brazilian localities due to high ingestion of fluoride from naturally fluoridated water or due to the association between fluoridated water intake and an uncontrolled ingestion of fluoridated products, particularly dentifrices. ${ }^{8,9,20,21,24,25,26}$ In Alagoas, a state of the Northeastern region of Brazil, the ingestion of fluoridated dentifrice (1,500 ppm) by young children accounted for $80 \%$ of the F-intake. ${ }^{14}$ However, the majority of the Brazilian data on F-exposure are from cities in the Southern and Southeastern regions of the country, where individuals are exposed to fluoridated water as well as other sources of fluoride. ${ }^{8,12,20}$ Therefore, a thorough observation of the isolated effect of fluoridated dentifrices ingestion during childhood is much more difficult.

The SB-Brasil study, conducted with a small sample, indicated a low dental fluorosis prevalence in João Pessoa $(<10 \%))^{5,19}$ Furthermore, empirical data show few clinical cases of microabrasion treatment, thus indicating low fluorosis severity. ${ }^{21,26} \mathrm{~A}$ bill presented in 2004 and later approved in May 2005 by the local health council has allowed water fluoridation since 2006. ${ }^{15,17}$ To date (June 2007), however, João Pessoa still does not have a fluoridated public water system. Thus, an epidemiologic study on dental fluorosis in João Pessoa before fluoridating the public water system is important, primarily because the data on dental fluorosis prevalence will be useful in future epidemiologic studies, and also because it will be possible to separately measure, in the same urban area, the contribution of fluoride intake from fluoridated dentifrices and from fluoridated water. The aim of this study was, therefore, to determine the prevalence of dental fluorosis among 12- to 15 year-old students from João Pessoa (PB), a non-fluoridated city that will start a program of artificial fluoridation of drinking water. The use of fluoridated dentifrice was also surveyed.

\section{Material and Methods Area studied}

João Pessoa has approximately 600 thousand inhabitants. ${ }^{18}$ The city had fluoridated water for a two year period in the middle of the 1980 s, but since then the project has been disabled. ${ }^{16}$ Nowadays, fluoride concentration in the water is very low as stated by Alves ${ }^{2}$ (2001) which monitored fluoride levels during 1 year and found it to be less than $0.1 \mathrm{ppm}$.

\section{Individuals}

Twelve to fifteen year old children, who were regularly attending public schools in the urban area of the city, were randomly chosen by cluster random sampling with a design effect of 2.0. A pilot study was conducted to estimate the prevalence of dental fluorosis in 4 schools $(\mathrm{n}=120)$, one in each zone of the city. The estimated prevalence observed was $21 \%$. Thus, the sample size was calculated assuming an expected prevalence of 0.21 , a $\mathrm{z}$ value of 1.96 and an absolute precision of 0.04. A minimum sample size of 797 students was determined. ${ }^{22}$ However, in order to avoid non-permanent residents in the sample and to compensate the refusals, a $30 \%$ increase in the calculated sample was carried out. ${ }^{6}$ Thus, a goal was set of at least 1,036 students to be selected. The clusters were drawn according to the population density of the target age group in the schools distributed in the 4 major city areas. ${ }^{18}$ Schools without 12-15-year-old students or with less than 10 students in that age group were not selected. A total of twenty-seven schools representing 18 neighborhood areas of the city were selected. It is worth mentioning that out of the 49 neighborhood 
areas of João Pessoa, 21 of them mainly have school children younger than 12 years old and therefore almost all schools were included in the study. ${ }^{18}$

In order to assure that individuals were exposed only to the water from João Pessoa during their life, the permanent residency of the subjects was checked in the schools and then recorded to the files. All students selected were examined; however, only permanent residents were considered for data analysis. Additionally, in order to be included in the research, after having been selected, the students had to meet the following criteria: complete teeth eruption, absence of lesion on the teeth, no orthodontic brackets. A total of 1,402 students were examined. However, 31 students refused to take part in the research and 257 were not permanent residents in João Pessoa, and thereby a final sample of 1,114 students was obtained.

\section{Questionnaire}

The students answered a 4-question form on the use of fluoridated dentifrice (if the student used it since childhood, and his/her preferred brand) and on oral hygiene habits (brushing frequency, and if he/she remembered ingesting dentifrice since childhood).

\section{Clinical examination}

The dental exam for fluorosis was carried out by two previously calibrated dentistry students. The calibration was carried out in two phases. Initially, the examiners were given a series of sixty random photographs of fluorosis cases (TF.0 - TF.7). Then, each student separately analyzed and gave TF scores. In a second stage, the calibration was conducted in schools with 40 students with varying fluorosis severities (TF.0 - TF.4). Comparing the scores from the examiners to the golden standard, the inter-examiner kappa index was calculated (Kappa index $=0.78$ ). Before the exam, the teeth were cleaned with gauze and dried for 30 seconds using an electric air compressor. The exams were carried out under natural indirect light during school hours and using wooden spatulas. Fluorosis severity was assessed using the TF inde ${ }^{28}$ for the buccal surface of each tooth. Upper and lower incisors, canines and premolars were examined. The overall fluorosis severity degree for each individual was based on the highest TF value found in the individual's oral cavity.

\section{Statistical study}

The data were put into tables in the SPSS program (v. 10.0). The chi-squared test was used when appropriate. Previously, a significance level of 5\% was established. Approximately $8 \%$ of the sample was re-examined to obtain an intra-examiner Kappa index. The intra-examiner Kappa index values were 0.88 and 0.80 for the first and second examiner, respectively.

\section{Ethical consideration}

Before beginning the research, the project was evaluated and approved by the Ethics in Research Committee, Health Sciences Center, Federal University of Paraíba (CEP/CCS-UFPB, protocol number 113/03). Consent forms were obtained from each student and from each school principle, thus complying with the legislation regarding research with human beings.

\section{Results}

Fluorosis prevalence in permanent-resident students in João Pessoa was $29.2 \% \quad(\mathrm{n}=325)$. The prevalence values were similar amongst the student age groups, with no statistical difference (Table 1).

A total of 537 males and 577 females were examined, and no relation between fluorosis prevalence and gender was found $\left(\mathrm{p}>0.05, \mathrm{df}=1, \chi^{2}=2.3\right)$. There was a slight decrease in the number of students as age increased. A total of 21,483 teeth were examined. Absent teeth added up to 797 , which is $3.7 \%$ of the total. The mainly absent teeth were canines $(\mathrm{n}=207)$. Upper premolars $(\mathrm{n}=4,212)$ were most affected by fluorosis $(21.1 \%$; $\mathrm{n}=889)$, followed by lower premolars ( $\mathrm{n}=4,224)$, from which $8.5 \%(n=359)$ were affected. From the canines examined $(\mathrm{n}=4,190), 4.0 \%(\mathrm{n}=169)$ were affected, and from the incisors examined $(\mathrm{n}=8,857), 2.3 \%$ ( $\mathrm{n}=201)$ were affected.

The fluorosis severity degree mostly observed was $\mathrm{TF}=1(66.8 \%)$, and the highest severity degree found in the research was TF $=4$ (Table 2). 
Table 1 - Fluorosis prevalence according to students' age. João Pessoa, 2004-2005*.

\begin{tabular}{|c|c|c|c|c|c|}
\hline \multirow{2}{*}{ Dental Fluorosis } & \multirow{2}{*}{$\mathrm{N}$} & \multicolumn{4}{|c|}{ Age (in years) } \\
\hline & & 12 & 13 & 14 & 15 \\
\hline Yes & 325 & 146 & 93 & 50 & 36 \\
\hline$\%$ & 29.2 & 28.0 & 32.4 & 26.9 & 30.0 \\
\hline $\mathrm{Cl}(\%)^{* *}$ & $26.5-31.9$ & $24.1-31.9$ & $27.0-37.8$ & $23.6-36.4$ & $21.8-38.2$ \\
\hline No & 789 & 375 & 194 & 136 & 84 \\
\hline$\%$ & 70.8 & 72.0 & 67.6 & 73.1 & 70.0 \\
\hline $\mathrm{Cl}(\%)^{* *}$ & $68.1-73.5$ & $68.1-75.9$ & $62.2-73.0$ & $66.7-79.5$ & $61.8-78.2$ \\
\hline Total & 1,114 & 521 & 287 & 186 & 120 \\
\hline
\end{tabular}

${ }^{*}\left(\chi^{2}=2.2, d f=3, p>0.05\right) ;{ }^{* *}$ Confidence Interval.

Table 2 - Distribution of the different fluorosis scores among 325 students. João Pessoa, 2004-2005.

\begin{tabular}{c|c|c|c|c|c}
\hline \multirow{2}{*}{ Total } & \multicolumn{4}{c}{ TF } \\
\cline { 3 - 6 } \multicolumn{2}{c|}{} & 1 & 2 & 3 & 4 \\
\hline$N$ & 325 & 217 & 34 & 67 & 07 \\
\hline$(\%)$ & $(100)$ & $(66.8)$ & $(10.5)$ & $(20.6)$ & $(2.2)$ \\
\hline
\end{tabular}

Among the 257 non-residents, the prevalence of dental fluorosis was $46 \%$. Most of them (43\%) had TF values of 1 to 3 .

In the majority of the city areas visited, a prevalence of less than $25 \%$ was observed. However, 4 city neighborhoods ("Tambaú", "Castelo Branco", "Cruz das Armas" and "Varadouro") presented a dental fluorosis prevalence above $36 \%$.

The majority of the students informed that they used fluoridated dentifrice since childhood, including brands that were not available on the marketplace at the time of the study; $95 \%$ of the preferred brands had a 1,500 ppm F concentration. Sixty five percent of the students reported that they brushed their teeth 3 times a day. A total of 366 students were unable to remember if they had ingested dentifrice during childhood, but 456 of them did remember they had ingested or still ingest dentifrice when brushing their teeth.

\section{Discussion}

The procedure of evaluating dental fluorosis only among lifelong residents has been recom- mended previously. ${ }^{27}$ Because of migration, many students were not accounted for in data analysis. The higher fluorosis prevalence of non-residents $(46 \%)$ could certainly have overestimated the real prevalence of dental fluorosis if this procedure had not been taken into consideration. This is particularly important since there are 3 large endemic fluorosis areas in Paraíba due to the presence of natural fluoride in ground waters. The prevalence of dental fluorosis in these areas can reach more than $70 \%$ among children and severe fluorosis can be found. ${ }^{24,26}$ Due to migration, the present study would certainly be biased if the lifelong residency criterion was disregarded.

Fluorosis prevalence in students from João Pessoa was higher than expected (Table 1). A lower prevalence value was predicted, as the city does not have fluoridated water. It is quite inadequate to compare this result with that of other studies due to the socio-cultural differences, as well as to the different indexes used to record fluorosis severity. The SB-Brasil study observed an $8.9 \%$ fluorosis rate in João Pessoa. ${ }^{19}$ Underestimation should be considered since the sample number was low and the Dean index, which does not ask for a clean and dry tooth surface before examination, was used. Unlike the TF index, ${ }^{23,28}$ the Dean index is not related to enamel histological features. The TF index would therefore be the most appropriate for a mild fluorosis scenario, especially in areas lacking water fluoridation. Underestimation cannot thus be disregarded in the study performed in Salvador, a city with fluoridated 
water that presented a $29 \%$ fluorosis rate using the Dean Index. ${ }^{9}$

Fluorosis prevalence above $36 \%$ was found in 4 areas of João Pessoa. These neighborhoods are considered central areas of the city, where living conditions are better than in the outskirts. It is therefore expected that even impoverished people that live in these areas are able to acquire oral hygiene goods more easily than those living in poorer neighborhoods.

Information about fluoride ingestion in João Pessoa is not available. However, there are many reasons to consider the fluoridated dentifrice as the main source of fluoride. First, water fluoridation stopped 20 years ago and, since that time, the fluoride levels have been very low. ${ }^{2}$ Secondly, other sources of fluoride, such as mineral water, are unlikely to have contributed because the local mineral water commercialized in the city has low fluoride levels. ${ }^{2,24,25}$ Thirdly, fluoride-rich dietary products could not be detected so far, and Albuquerque et al. ${ }^{1}$ (2003) reported that the use of fluoridated dentifrice in young ages is common in João Pessoa. Additionally, our data support that this habit may go on until adolescence for some subjects. Finally, a survey of fluoride intake showed that $80 \%$ of the fluoride ingested by children in other cities of Paraíba came from dentifrices. ${ }^{25}$ In spite of the existence of only two reports, the ingestion of dentifrice among the children in the Northeast region of Brazil is higher than that reported in other Brazilian studies. ${ }^{8,12,14}$ A study about cultural habits is warranted for this issue. A recent document reported that, in Paraíba, some persons are adding amounts of dentifrice to water and other drinking products to produce a "cool water" sensation. ${ }^{4}$ If this habit is common among children, the risk of dental fluorosis can be high.

The difference between fluorosis prevalence in fluoridated and non-fluoridated regions is decreasing. ${ }^{25}$ Some studies have currently reported higher fluorosis prevalence in areas without water fluoridation in comparison to areas with water fluoridation, whereas better oral health conditions are frequent in areas of fluoridated water. ${ }^{11}$ Therefore, a water fluoridation program in João Pessoa is necessary since caries experience is still high among adolescents $(\mathrm{DMFT}=3.5$ among 12-year-old children) and in young children. ${ }^{12,16}$ The majority of the fluorosis cases observed was $\mathrm{TF}=1$. As the $\mathrm{TF}$ index ranges from 0 to 9 , such a score represents thin opaque white lines on the enamel, which can only be clearly observed when the tooth surface is clean and dry. ${ }^{28}$ Under regular oral conditions, with the enamel covered by dental plaque and saliva, that level of dental fluorosis is not considered an aesthetic problem, thus suggesting that the majority of the cases observed in this study cannot be regarded as a public health problem (Table 2). A fluoridation program can, therefore, be safely recommended. An increase in dental fluorosis prevalence due to the association of dentifrice ingestion and water fluoridation can be expected. On the other hand, it is important to mention that an increase in the fluorosis prevalence does not mean an increase in fluorosis severity. Having this study's results in hand, it is difficult to identify the fluoride sources involved, but it is possible to support that water fluoridation had no effect on the actual fluorosis prevalence observed in the studied group.

\section{Conclusions}

1. Dental fluorosis prevalence among students from João Pessoa was higher than expected for an area with a non-fluoridated water supply.

2. Most students used highly fluoridated dentifrices, and almost half ingested slurry while brushing.

3. The great majority of fluorosis cases had little aesthetic relevance, thus suggesting that dental fluorosis should not be considered as a public health problem.

\section{Acknowledgments}

This study was supported by the National Council for Scientific and Technological Development (CNPq). 


\section{References}

1. Albuquerque SSL, Lima MGGC, Sampaio FC. Utilização de dentifrício fluoretado por crianças de 2 a 5 anos na cidade de João Pessoa, Paraíba. Odontol Clin Cient. 2003;2(3):211-6.

2. Alves NSS. Situação da fluoretação de águas de abastecimento público no estado da Paraíba [Monografia de Especialização]. João Pessoa: Universidade Federal da Paraíba; 2001.

3. Birkeland JM, Haugejorden O, von der Fehr FR. Some factors associated with the caries decline among Norwegian children and adolescents: age-specific and cohort analyses. Caries Res. 2000;34(2):109-16.

4. Brasil. Ministério da Saúde. Fundação Nacional de Saúde. Departamento de Saúde Indígena. Uso indevido de creme dental. [s.l.]. Fundação Nacional de Saúde; 2005. Memorando circular n. 100 COOPE/DESAI.

5. Brasil. Ministério da Saúde. Secretaria de Atenção à Saúde. Departamento de Atenção Básica. Coordenação Nacional de Saúde Bucal. Projeto SB Brasil 2003: condições de saúde bucal da população brasileira no ano 2002-2003. Resultados Principais. Brasília: Ministério da Saúde; 2004.

6. Brasil. Ministério da Saúde. Secretaria de Políticas Públicas. Departamento de Atenção Básica. Área Técnica de Saúde Bucal. Projeto SB2000: condições de saúde bucal da população brasileira no ano 2000: manual do coordenador. Brasília: Ministério da Saúde; 2001.

7. Bratthall D. Dental caries: intervened - interrupted - interpreted. Concluding remarks and cariography. Eur J Oral Sci. 1996;104(4 pt 2):486-91.

8. Buzalaf MFR. Fatores de risco para fluorose dentária e biomarcadores de exposição ao flúor [Tese de Livre Docência]. Bauru: Faculdade de Odontologia de Bauru da USP; 2002.

9. Cangussu MCT, Castellanos Fernandez RA, Rivas CC, Ferreira Jr C, Santos LC. Prevalência da fluorose dentária em escolares de 12 e 15 anos de idade em Salvador, Bahia, Brasil, 2001. Cad Saúde Pública. 2004;20(1):129-35.

10. Cangussu MCT, Narvai PC, Castellanos Fernandez R, Djehizian V. A fluorose dentária no Brasil: uma revisão crítica. Cad Saúde Pública. 2002;18(1):7-15.

11. Cypriano S, Pecharki GD, Sousa MLR de, Wada RS. A saúde bucal de escolares residentes em locais com e sem fluoretação nas águas de abastecimento público na região de Sorocaba, São Paulo, Brasil. Cad Saúde Pública. 2003;19(4):1063-71.

12. Lima YBO, Cury JA. Seasonal Variation of Fluoride Intake by Children in a Subtropical Region. Caries Res. 2003;37(5): 335-8.

13. Narvai PC, Castellanos RA, Frazão P. Prevalência de cárie em dentes permanentes de escolares do Município de São Paulo, SP, 1970-1996. Rev Saúde Pública. 2000;34(2):196-200.

14. Omena LMF, Silva MF de A, Pinheiro CC, Cavalcante JC, Sampaio FC. Fluoride intake from drinking water and dentifrice by children living in a tropical area of Brazil. J Appl Oral Sci. 2006;14(5):382-7.
15. Paraíba. Assembléia Legislativa do Estado da Paraíba. Projeto de lei $n^{\circ} 554 / 2004$. Dispõe sobre a fluoretação da água destinada para o consumo humano na Paraíba. Ata de sessão, jun 2004:3.

16. Paraíba. Companhia de Água e Esgotos da Paraíba. Lista de cidades com fluoretação de águas. Relatório Técnico; 1996, Ago:3.

17. Paraíba. Conselho Municipal de Saúde de João Pessoa. Resolução n. 09 de 05 de maio de 2005. Ata de sessão; 2005:25.

18. Paraíba. Secretaria de educação e cultura do estado da Paraíba. Relatório de geoprocessamento; 2004.

19. Paraíba. Secretaria de Saúde. Dados parciais do SB Brasil 2003. João Pessoa; 2004.

20. Pereira AC, Da Cunha FL, Meneghim M de C, Werner CW. Dental caries and fluorosis prevalence study in a nonfluoridated Brazilian community: trend analysis and toothpaste association. ASDC J Dent Child. 2000;67(2):132-5.

21. Pereira TB, Sampaio FC. Hábitos de escovação dental de crianças em áreas de fluorose endêmica do estado da Paraíba [CDROM]. In: Anais do $21^{\circ}$ Congresso Internacional de Odontologia de São Paulo; 2003 jan 27-30; São Paulo. São Paulo: APCD; 2003.

22. Rodrigues PC. Bioestatística. Niterói: EDUFF; 1986.

23. Rozier RG. Epidemiologic indices for measuring the clinical manifestations of dental fluorosis: overview and critique. Adv Dent Res. 1994;8(1):39-55.

24. Sampaio FC. Fluoride exposures and biomarkers in humans [PhD Dissertation]. Oslo: School of Dentistry, University of Oslo; 2000.

25. Sampaio FC, Kehrle HM, Carvalho TS. Monitoreo de la ingestión de fluoruros en niños del interior de Paraiba [abstract]. In: Resúmenes de la XI Reunión Anual de la Asociación de Investigación Odontológica del Peru: 2004; Lima. Asociación de Investigación Odontológica del Peru: 2004. p. 35.

26. Sampaio FC, Mendes ACR, Pires GR. Remoção de manchas de fluorose pela técnica de CROLL - Descrição de caso clínico. Revista da ABO. 1997;5(3):153-6.

27. Selwitz RH, Nowjack-Raymer RE, Kingman A, Driscoll WS. Dental caries and dental fluorosis among schoolchildren who were lifelong residents of communities having either low or optimal levels of fluoride in drinking water. J Public Health Dent. 1998;58(1):28-35.

28. Thylstrup A, Fejerskov O. Clinical appearance of dental fluorosis in permanent teeth in relation to histological changes. Community Dent Oral Epidemiol. 1978;6(6):315-28.

29. Villena RS, Cury JA. Flúor: aplicação sistêmica. In: Correia MSNP. Odontologia para a primeira infância. São Paulo: Santos; 1998. p. 291-314.

30. von der Fehr FR. Evidence of decreasing caries prevalence in Norway. J Dent Res. 1982;61(special issue):1331-5. 